Illinois State University

ISU ReD: Research and eData

Theses and Dissertations

3-29-2021

\title{
Effects Of The Antidepressant Drug Vortioxetine On Ventral Pallidal Neuronal Activity, Respiration, And Heart Rate In The Rat
}

Piper Rogers

Illinois State University, pbroger@ilstu.edu

Follow this and additional works at: https://ir.library.illinoisstate.edu/etd

Part of the Neuroscience and Neurobiology Commons

\section{Recommended Citation}

Rogers, Piper, "Effects Of The Antidepressant Drug Vortioxetine On Ventral Pallidal Neuronal Activity, Respiration, And Heart Rate In The Rat" (2021). Theses and Dissertations. 1406.

https://ir.library.illinoisstate.edu/etd/1406

This Thesis is brought to you for free and open access by ISU ReD: Research and eData. It has been accepted for inclusion in Theses and Dissertations by an authorized administrator of ISU ReD: Research and eData. For more information, please contact ISUReD@ilstu.edu. 


\section{EFFECTS OF THE ANTIDEPRESSANT DRUG VORTIOXETINE ON VENTRAL PALLIDAL NEURONAL ACTIVITY, RESPIRATION, AND HEART RATE IN THE RAT}

\section{PIPER ROGERS}

\section{Pages}

Major Depressive Disorder (MDD) is a mental illness that affects millions of people worldwide. People diagnosed with MDD are often prescribed antidepressant drugs. Most antidepressants increase levels of serotonin (5-hydroxytryptamine, 5-HT) in the synapses between neurons. Selective-serotonin reuptake inhibitors (SSRIs), one class of antidepressants, do this by inhibiting the reuptake of serotonin released into the synapse. Serotonin neurons from the brainstem raphe nuclei affect a wide range of areas throughout the brain. Among these areas is the ventral pallidum (VP), located in the basal forebrain. Citalopram, an SSRI, has been found to increase the firing rate of action potentials of neurons in the VP of rats. The VP also projects to areas that are thought to be involved with MDD.

A novel antidepressant, vortioxetine, has been developed that has multimodal actions. Vortioxetine inhibits the serotonin transporter as previous SSRI drugs do, but also is a $5-\mathrm{HT}_{1 \mathrm{~A}}$ receptor agonist, 5- $\mathrm{HT}_{1 \mathrm{~B}}$ receptor partial agonist, and a 5- $\mathrm{HT}_{1 \mathrm{D}}, 5-\mathrm{HT}_{3}$, and $5-\mathrm{HT}_{7}$ receptor antagonist. In the present study, we attempted to investigate the effects of vortioxetine on neuronal activity in the VP of urethane-anesthetized rats through extracellular single-unit electrophysiological techniques. We also measured heart rate and respiration rate, as the 5-HT system is closely related to cardiac and respiratory function. We hypothesized that vortioxetine 
would increase the frequency of action potentials in the VP and decrease cardiac activity and respiration rate, as citalopram did. However, the multiple actions of vortioxetine could produce qualitatively or quantitatively different effects from citalopram. It was found that increasing doses of vortioxetine slightly increased, and then dramatically decreased heart rate in the majority of rats tested. Vortioxetine most frequently increased respiration rate in the rats examined. The results of this study are compared to citalopram and assist in further understanding of the actions of vortioxetine as an effective and novel antidepressant.

KEYWORDS: Vortioxetine; Ventral Pallidum; Major Depressive Disorder, 5-HT ${ }_{1 \mathrm{~A}}$ agonist, electrophysiology 
EFFECTS OF THE ANTIDEPRESSANT DRUG VORTIOXETINE ON VENTRAL

PALLIDAL NEURONAL ACTIVITY, RESPIRATION, AND HEART RATE IN THE RAT

PIPER ROGERS

A Thesis Submitted in Partial
Fulfillment of the Requirements
for the Degree of
MASTER OF SCIENCE
Department of Psychology
LLINOIS STATE UNIVERSITY

2021 
Copyright 2021 Piper Rogers 
EFFECTS OF THE ANTIDEPRESSANT DRUG VORTIOXETINE ON VENTRAL

PALLIDAL NEURONAL ACTIVITY, RESPIRATION, AND HEART RATE IN THE RAT

PIPER ROGERS

COMMITTEE MEMBERS:

Byron Heidenreich, Chair

Paul Garris 


\section{ACKNOWLEDGMENTS}

I would like to begin by thanking my committee chair, Dr. Byron Heidenreich. Without your knowledge and constant support, none of this would have been possible. You have given me the experience I need to succeed in the world of scientific research and for that I will be forever grateful. I also want to thank Dr. Paul Garris for being a helpful and dedicated committee member. I would also thank to thank Dr. Dan Lannin for participating as the reader for this thesis. Additionally, I would like to thank H. Lundbeck A/S in Valby, Denmark for supplying the vortioxetine.

I also want to thank my father, John Rogers. Attending graduate school in general would have not been possible if it wasn't for his significant financial support. I also want to thank him for his constant love and encouragement. I would like to thank my brother as well, Dr. Oliver Rogers, for inspiring me to be the best scientist I can be and being an overall role model.

Finally, I would like to thank my boyfriend, Christian Holsker, for everything he has done for me and my graduate school career in the last 4 years. His endless support has been a necessity in graduating from graduate school, and without him, I don't know that I would have made it this far. From comforting me after stressful lab days, to editing all my papers, he has been there through everything. My eternal thanks and love, puntin.

P. B. R. 


\section{CONTENTS}

Page

ACKNOWLEDGMENTS

$\begin{array}{ll}\text { CONTENTS } & \text { ii }\end{array}$

CHAPTER I: BACKGROUND AND REVIEW OF RELATED RESEARCH 1

Major Depressive Disorder 1

5-HT Receptors

$\begin{array}{ll}\text { Ventral Pallidum } & 3\end{array}$

$\begin{array}{ll}\text { Nucleus Accumbens } & 5\end{array}$

$\begin{array}{ll}\text { Vortioxetine } & 7\end{array}$

$\begin{array}{ll}\text { Heart Rate } & 10\end{array}$

Respiration Rate $\quad 11$

CHAPTER II: CURRENT STUDY 13

$\begin{array}{ll}\text { Method } & 13\end{array}$

$\begin{array}{ll}\text { Subjects } & 13\end{array}$

Materials and Procedure 13

$\begin{array}{ll}\text { CHAPTER III: RESULTS } & 16\end{array}$

$\begin{array}{ll}\text { Neural Activity } & 16\end{array}$

$\begin{array}{ll}\text { Heart Rate } & 17\end{array}$

$\begin{array}{ll}\text { Respiration Rate } & 18\end{array}$

$\begin{array}{ll}\text { CHAPTER IV: DISCUSSION } & 20\end{array}$

$\begin{array}{ll}\text { General Discussion } & 20\end{array}$

$\begin{array}{ll}\text { Limitations } & 22\end{array}$ 
CHAPTER V: CONCLUSION

REFERENCES

APPENDIX A: TABLES

APPENDIX B: FIGURES 


\section{CHAPTER I: BACKGROUND AND REVIEW OF RELATED RESEARCH}

\section{Major Depressive Disorder}

Major Depressive Disorder is a mental illness that affects over 350 million people worldwide (Marcus et al., 2004) and is characterized by depressed mood, anhedonia, sleep disturbances and apathy, among many other symptoms. Most antidepressants increase levels of serotonin (5-hydroxytryptamine, 5-HT) in the synapses between neurons. It is well-known that selective-serotonin reuptake inhibitors (SSRIs) increase 5-HT in synapses by decreasing the amount of 5-HT that is taken back up into the presynaptic neuron, thereby increasing 5-HT's presence in the synapse and magnifying its effects. Thus, when antidepressants are administered, 5-HT neurotransmission is enhanced by delayed clearance of serotonin. Though the development of SSRIs is a major progression in the treatment of depression, there are still problems associated with this class of antidepressants. For example, SSRIs have a similar issue as tricyclic antidepressants, in that there is a period of time prior to clinical improvement, known as therapeutic lag. Also, approximately one-third of depressed patients do not respond favorably to SSRIs or other antidepressants (Blier \& Montigny, 1999). Fortunately, new antidepressants are being developed every year to combat these issues.

\section{5-HT Receptors}

Antidepressants cause their therapeutic effects in part by increasing serotonin in the synapses of the brain, which then acts on various 5-HT receptors that exist in many areas. 5-HT receptors are located throughout the brain and are expressed on both excitatory and inhibitory neurons. The resulting action on the neuron is largely dependent on which 5-HT receptors are expressed by the neuron, among other factors (Leiser et al., 2015). Therefore, the type of 5-HT receptor that is present on the neuron is vital in understanding the actions of 5-HT. 
There are many subtypes of 5-HT receptors, including 5-HT receptors one through seven. The 5- $\mathrm{HT}_{1}$ receptor family, including 5-HT $\mathrm{H}_{1 \mathrm{~A}}$ and 5-HT $\mathrm{H}_{1 \mathrm{~B}}$ receptors, are inhibitory receptors. Researchers found that within the dorsal raphe nucleus (where 5-HT neurons originate), there is a high density of 5-HT $\mathrm{H}_{1 \mathrm{~A}}$ receptors (Pompeiano et al., 1992) that are found exclusively on cell bodies and dendrites of neurons (Riad et al., 2000). This location makes these receptors ideal candidates to be both autoreceptors and heteroreceptors (Riad et al. 2000). While 5-HT $1 \mathrm{~A}$ agonists can produce a wide range of effects (Leiser et al., 2015), both 5-HT $\mathrm{HA}_{1 \mathrm{~A}}$ autoreceptors and heteroreceptors seem to decrease the firing rate of neurons in various parts of the brain (Chaput and Montigny, 1988). 5- $\mathrm{HT}_{1 \mathrm{~A}}$ receptors on the cell body of neurons containing 5-HT hyperpolarize the membranes of the neurons by opening potassium channels (Blier and Montigny, 1999). SSRIs and 5-HT1A agonists induce an initial reduction in the firing of 5-HT neurons as they increase the activation of the somatodendritic 5- $\mathrm{HT}_{1 \mathrm{~A}}$ autoreceptor (Blier and Montigny, 1983). Stimulation of postsynaptic 5- $\mathrm{HT}_{1 \mathrm{~A}}$ receptors by $5-\mathrm{HT}$ or direct 5- $\mathrm{HT}_{1 \mathrm{~A}}$ agonists produces a similar hyperpolarization and inhibition of activity (Haddjeri et al., 1998). Similar to 5-HT 1 A receptors, 5- $\mathrm{HT}_{1 \mathrm{~B}}$ receptors can be both autoreceptors and heteroreceptors and can cause inhibitory activity in neurons. They are thought to be located on the presynaptic terminals of 5-HT neurons (Sari, 2004). Researchers found that within both the substantia nigra and the globus pallidus, $5-\mathrm{HT}_{1 \mathrm{~B}}$ receptors were also found on the membrane of preterminal axons. This location suggests that $5-\mathrm{HT}_{1 \mathrm{~B}}$ receptors mediate neurotransmitter release, because these receptors are able to mediate 5-HT induced changes in the conduction of the axon (Riad et al., 2000). In both cases, these receptors control the inhibition of 5-HT release or another neurotransmitter in various areas of the brain (Engel et al., 1986). 
There is much less known about 5-HT $1 \mathrm{D}$ receptors than $5-\mathrm{HT}_{1 \mathrm{~A}}$ or $5-\mathrm{HT}_{1 \mathrm{~B}}$ receptors. However, researchers have shown that activation of 5- $\mathrm{HT}_{1 \mathrm{D}}$ receptors in the dorsal raphe nuclei decreases the amount of 5-HT around the cell bodies that is released by electrical stimulation (Davidson et al., 1995). This activation did not directly modulate firing activity, however (Roberts et al., 1997).

5-HT 3 receptors are excitatory receptors and seem to be located postsynaptically (Leiser et al., 2015). The 5- $\mathrm{HT}_{3}$ receptor is thought to have a role in cognition, such as memory, attention, and processing speed (Ladefoged, 2018).

5- $\mathrm{HT}_{7}$ receptors are excitatory receptors and seem to be expressed on GABAergic neurons (Vysokanov et al., 1998). The activation of 5- $\mathrm{HT}_{7}$ receptors creates a positive feedback loop, as it decreases GABA release, which disinhibits 5-HT neurons, resulting in an increased level of synaptic 5-HT (Roberts et al., 2004). In conclusion, 5-HT is able to modulate neural circuits in many ways through activating its various receptor subtypes.

\section{Ventral Pallidum}

5-HT neurons that originate in the brainstem raphe nuclei affect a wide range of areas throughout the brain. For example, 5-HT neurons in the dorsal raphe nucleus project to areas in the basal forebrain, including the ventral pallidum (VP) and overlapping nucleus basalis. Consequently, 5-HT has been detected in the VP using microdialysis studies in rats (Sizemore, 2000). In turn, the VP projects to the raphe nuclei, and synapses onto dorsal raphe nuclei 5-HT neurons (Pollak-Dorocic et al., 2014).

The VP's main function is its role in processing and executing motivated behaviors. It regulates motor functions that lead to the obtaining of a reward. The VP has shown to be an area important for self-stimulation, in that animals will deliver an electrical stimulus to the VP in 
order to feel a sense of obtaining a reward (Panagis et al., 1995). It is also involved with drugseeking behavior and addiction. It is also thought to be important for emotion processing and have a role in many psychiatric disorders, such as depression (Root, Melendez, Zaborszky, \& Napier, 2015).

A majority, around $80 \%$, of the neurons in the VP are GABAergic neurons (Zahm et al., 1985). GABAergic inputs can be modulated by the different types of 5-HT receptors (Leiser et al., 2015). The VP and nucleus basalis also contain cholinergic neurons. Cholinergic neurons in the VP provide a large amount of input to the amygdala, a major area responsible for emotions (Carlsen et al., 1985). The dorsal raphe nuclei project to these cholinergic neurons in the nucleus basalis (Jones and Cuello, 1989).

Regarding noncholinergic neurons, 5-HT applied to these cells in the guinea pig nucleus basalis in vitro hyperpolarized most of the neurons in two out of three groups of cells pharmacologically characterized by their responses to noradrenaline and muscarine (Fort et al., 1998). However, 5-HT has been reported to depolarize noncholinergic neurons within the rat VP in an in vitro study (Bengtson et al., 2004).

Regarding cholinergic neurons within the guinea pig nucleus basalis, 5-HT and 5-HT $1 \mathrm{~A}$ agonists in vitro produced a hyperpolarization in 26 out of 31 neurons and in 6 out of 6 experiments conducted, respectively, suggesting that 5-HT and 5-HT $\mathrm{H}_{1 \mathrm{~A}}$ receptors inhibit activity within the nucleus basalis (Khateb et al., 1993). Similarly, 5-HT hyperpolarizes cholinergic neurons within the rat VP in vitro (Bengtson et al., 2004).

Heidenreich and Napier (2000) conducted an experiment in anesthetized rats investigating the effects of activating $5-\mathrm{HT}_{1 \mathrm{~A}}$ and $5-\mathrm{HT}_{1 \mathrm{~B}}$ receptors on VP firing rate in vivo using the 5- $\mathrm{HT}_{1 \mathrm{~A}}$ agonist 8-OH-DPAT, the 5-HT $1 \mathrm{~B}$ agonist $\mathrm{CP}-94253$, and the non-selective 5- 
HT agonist TFMPP. They recorded baseline activity in the VP in rats and then injected rats with increasing doses of 8-OH-DPAT, CP-94253, or TFMPP. Neuronal responses were considered significant when firing rate was changed by at least $20 \%$ from baseline. Researchers found that 8-OH-DPAT caused both increases and decreases in VP firing rate; however, increases in firing rate were observed with lower doses. They also found that four neurons displayed a biphasic response. CP-94253 most often produced no change in firing rate. Their last finding was that TFMPP dose-dependently decreased neuronal activity in the VP. From these results, researchers were able to conclude that 5-HT neurotransmission plays a role in regulating neuronal firing rate in the VP.

As with direct agonists, it is possible for antidepressants to modify the firing rate of the VP as well. Morrison and Heidenreich (2010) conducted an experiment investigating the effects of citalopram, an SSRI, on VP neuronal activity as well as heart rate and respiration rate in anesthetized rats. They recorded action potentials from VP neurons using electrophysiological procedures, with neural responses to citalopram considered significant when activity changed by at least $20 \%$ from basal levels. Their main finding was that citalopram primarily increased the firing rate of the majority of VP neurons. They also found the citalopram decreased heart rate and respiration rate in the majority of rats tested. Morrison and Heidenreich's (2010) fundamental conclusion from their experiment was that the 5-HT system influences VP neuronal activity, as well as respiration and heart rate, in rats and that this is altered by antidepressants.

\section{Nucleus Accumbens}

There are several brain structures that project to the VP and affect its activity. Included in these areas are the dorsal raphe nucleus, as previously mentioned, as well as the nucleus accumbens. The nucleus accumbens represents the largest input to the VP (Chrobak and Napier, 
1993). Like the VP, the nucleus accumbens is thought to play a role in MDD, as well as have a hand in motivation and reward mechanisms. It has been suggested that the dysfunction of the nucleus accumbens produces anhedonia in MDD patients (Shirayama and Chaki, 2006). Since the motivation-reward circuit is malfunctioning, it seems inevitable that a diminished interest or pleasure in once preferred activities would develop. There are also serotonergic afferents to the nucleus accumbens, which are thought to play a role in motivation and stress (McEwen et al., 1993), both of which can be involved with symptoms of depression.

The nucleus accumbens contains GABA and cholinergic interneurons, but mostly it contains efferent GABAergic projection neurons (Meredith et al., 1993). GABA neurons from the nucleus accumbens core project to the VP, the ventral tegmental area, hypothalamus, and the amygdala (Meredith et al., 1993). The GABAergic projection neurons are regulated by serotonergic afferents from the dorsal raphe nucleus (Shirayama and Chaki, 2006). Nucleus accumbens shell and core projections to the VP can synapse onto cholinergic neurons as well (Grove et al., 1986).

In the shell of the nucleus accumbens, 5-HT has mostly inhibitory activity on GABA neurons (Van Bockstaele et al., 1996). It has also been observed that 5-HT and GABAergic terminals converge onto cholinergic neurons (Van Bockstaele, 1996). This led researchers to believe that 5-HT has an inhibitory effect on cholinergic neurons and a disinhibition effect for GABAergic neurons in the nucleus accumbens (Shirayama and Chaki, 2006).

Serotonergic activity regulates dopamine release in the nucleus accumbens. It has been reported that application of 5-HT into the nucleus accumbens stimulates the release of dopamine (Parsons and Justice, 1993). Therefore, it has been suggested that the faulty regulation of forebrain dopamine neurotransmission by midbrain $5-\mathrm{HT}$ and $5-\mathrm{HT} 2 \mathrm{C}$ receptors contributes to 
MDD (Di Matteo et al., 2001). Evidence of this was observed when researchers showed that with the chronic administration of antidepressants, the 5-HT-dopamine system increased dopamine in the nucleus accumbens (Zangen et al., 2001). 5-HT receptor subtypes are found all throughout the nucleus accumbens (Pazos and Palacios, 1985) and are also involved in the dopaminergic system. For example, the activation of 5- $\mathrm{HT}_{1 \mathrm{~A}}$ and $5-\mathrm{HT}_{3}$ receptors causes an increase in dopamine release within the nucleus accumbens (Parsons and Justice, 1993; Campbell and McBride, 1995). In addition, it was discovered that 5-HT inhibited dopamine-sensitive nucleus accumbens neurons that receive input from parafascicular nucleus of the thalamus by activation

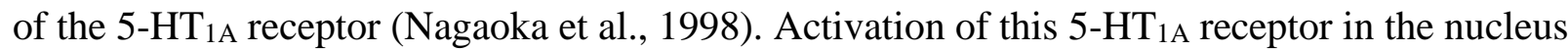
accumbens is thought to produce antidepressant effects seen with 5- $\mathrm{HT}_{1 \mathrm{~A}}$ agonists, such as buspirone (Nagaoka et al., 1998). The VP, the dorsal raphe nucleus and the nucleus accumbens are all connected and can have their firing rates altered by the administration of numerous serotonergic drugs.

\section{Vortioxetine}

A new antidepressant, vortioxetine, was approved for treatment for MDD in 2013. Similar to citalopram, vortioxetine also blocks the reuptake of 5-HT, as it was found that vortioxetine dose-dependently occupies the serotonin transporter (SERT) (Pehrson et al., 2012). This drug can exert its antidepressant effects at just 50\% occupancy of the SERT, while other antidepressants require 80\% occupancy (Sanchez et al., 2015; Meyer et al., 2004). It also showed positive effects during tests in animal models of depression such as the forced swim test (Guilloux et al., 2013) and has been found to significantly increase extracellular 5-HT levels in rats in the ventral hippocampus, medial prefrontal cortex, nucleus accumbens, and the dorsal raphe nuclei (Pehrson et al., 2013; Pehrson et al., 2012). Additionally, in a study by Eskelund et 
al. (2017), researchers administered vortioxetine in rat depression models for two weeks and found that vortioxetine reduced 5-HT in the brain, as well as 5-HIAA, a metabolite of 5-HT. This result is most likely due to the reduced activity of the serotonin transporter, leading to decreased serotonin in the presynaptic neuron. They also found that, at therapeutic doses, vortioxetine reduced levels of the neurotoxin, quinolinic acid (QUIN), which has been shown to be positively correlated with the severity of depression symptoms in depressed patients (Guillemin, 2012; Eskelund et al., 2017). In all brain regions, QUIN was reduced by 29\%, and in rat plasma, QUIN decreased by $50 \%$ (Eskelund et al., 2017).

Vortioxetine, however, is considered a multimodal antidepressant, in that is has several mechanisms of action and acts on many of the 5-HT receptors. It is a $5-\mathrm{HT}_{1 \mathrm{~A}}$ receptor agonist, a 5- $\mathrm{HT}_{1 \mathrm{~B}}$ receptor partial agonist, and a 5- $\mathrm{HT}_{1 \mathrm{D}}, 5-\mathrm{HT}_{3}$, and 5- $\mathrm{HT}_{7}$ receptor antagonist. These additional mechanisms of action are thought to have additional clinical benefits relative to other SSRIs, such as improved cognitive function (Gonda et al., 2018), especially through the 5- $\mathrm{HT}_{3}$ receptor (Ladefoged, 2018).

Vortioxetine's antidepressant effects seem to result from its activation of 5- $\mathrm{HT}_{1 \mathrm{~A}}$ and 5$\mathrm{HT}_{3}$ receptors, as well as the subsequent effect on GABAergic transmission (Gonda et al., 2018). This effect is not found in any other antidepressants. In an electrophysiological study by Betry et al. (2013), researchers found that after acute administration of vortioxetine, the firing rate of 5HT neurons in the dorsal raphe was dramatically suppressed. Researchers believe this is due to the increased availability of synaptic 5-HT resulting from both the inhibition of the 5-HT transporter and the activation of the various receptors. Researchers also discovered that when researchers administered a 5-HT $1 \mathrm{~A}$ antagonist, the effect was reversed. Bétry et al. (2013) also found that after chronic administration of vortioxetine, the $5-\mathrm{HT}_{1 \mathrm{~A}}$ receptor becomes 
desensitized, and normal firing activity resumes after just 3 days (similar to SSRIs, however, with SSRIs, it takes two to three weeks for firing activity to return to normal) (Blier and Montigny, 1983). Researchers have also found that vortioxetine increased the tonic activation of 5- $\mathrm{HT}_{1 \mathrm{~A}}$ receptors on neurons in the hippocampus (Mansari et al., 2015), eventually resulting in the receptors' desensitization as well as increased 5-HT neurotransmission in the hippocampus.

There is a similar effect with the 5- $\mathrm{HT}_{1 \mathrm{~B}}$ receptors. These receptors are located on the terminals of neurons, where they too have an inhibitory effect on 5-HT release. It has been found that after chronic administration of SSRIs, the 5- $\mathrm{HT}_{1 \mathrm{~B}}$ receptor desensitizes, and returns 5-HT transmission to normal levels (Blier and Bouchard, 1994). Mansari et al., 2015 found that 5-HT ${ }_{1 \mathrm{~B}}$ receptors in the hippocampus desensitized with chronic administration of vortioxetine under high, but not low, levels of activation. This provides evidence that vortioxetine does in fact, work as only a partial agonist at the $5-\mathrm{HT}_{1 \mathrm{~B}}$ receptor, as vortioxetine does not seem to affect the 5$\mathrm{HT}_{1 \mathrm{~B}}$ receptor $100 \%$ of the time, as a full agonist would.

By examining the occupancy of the 5- $\mathrm{HT}_{1 \mathrm{~B}}$ receptor in the ventral portion of the striatum, researchers concluded that vortioxetine, but not an SSRI, has an effect on this area. Also examined was the expression pattern of the 5- $\mathrm{HT}_{1 \mathrm{~A}}$ receptors in the septum. This region showed an increase in connectivity with the somatosensory cortex after vortioxetine injections, but not with an SSRI (Perez et al., 2018). Further, researchers examined a part of the hippocampus known for expressing 5-HT $1 \mathrm{~B}$ receptors and found that vortioxetine increased connectivity between the hippocampus and the medial prefrontal cortex, but an SSRI did not (Perez et al., 2018). Perez et al. (2018) concluded from this experiment that vortioxetine has the ability to affect connectivity of several different brain regions with 5-HT expression. 
Vortioxetine is also unique in that it initially works as a partial agonist at the $5-\mathrm{HT}_{3}$ receptor, followed by intense antagonism (Dale et al. 2018) Vortioxetine's activity as a 5-HT 3 receptor antagonist has been shown to block the activity of GABAergic interneurons in the ventral hippocampus, resulting in increased activity in that area. This mechanism is thought to potentially have a therapeutic effect of the cognitive symptoms of MDD (Dale et al., 2014). The 5-HT 3 receptor also has a high occupancy after vortioxetine administration, further increasing the antidepressant effects of the drug (Sanchez et al., 2015; Meyer et al., 2004).

A study was conducted to determine resting-state functional connectivity after vortioxetine administration. Researchers found that vortioxetine mostly affected connections between association cortices and sensorimotor cortices as well as striatum-sensorimotor cortices; vortioxetine also affected connections between the thalamus and hypothalamus, and the hippocampus and retrohippocampus (Perez et al., 2018). It is clear that vortioxetine has antidepressant effects and affects a wide range of brain areas through multiple actions.

\section{Heart Rate}

It is well-known that 5-HT and brainstem 5-HT neurons influence cardiac function. For example, intracerebroventricular administration of 5-HT causes bradycardia in rats (Wang et al., 1995). Studies have shown that antidepressants have the ability to decrease heart rate. In one study, researchers found that low doses of citalopram decreased heart rate in rabbits (Bo et al., 1987). Also, Morrison and Heidenreich (2010) found that a majority of rats tested displayed a decreased heart rate after i.v. injections of citalopram. It is possible that the bradycardia observed in these experiments is the result of 5-HT activation of the 5- $\mathrm{HT}_{1 \mathrm{~A}}$ receptor. The activation of this receptor by 8-OH-DPAT given i.v. has previously been shown to decrease heart rate in rats (Heidenreich \& Kempel, 2005). It has been suggested that the vagus nerve may have a role in the 
bradycardia caused by $5-\mathrm{HT}_{1 \mathrm{~A}}$ receptor activation. King and Holtman (1990) found that when the vagus nerve is removed, there is no bradycardia observed after administration of 8-OH-DPAT.

The dorsal vagal motor nucleus (DVM) is innervated by brainstem 5-HT neurons (Hopkins, 1987). The DVM gives rise to vagal motor neurons (Jordan, 1988) which regulate heart rate (Steinbusch, 1981). These neurons are thought to have 5-HT 1 A receptors (Pazos \& Palacios, 1985) and iontophoretic application of 5-HT into the DVM activates vagal motor neurons (Wang et al., 1995). Additionally, researchers found that the microinjection of 5-HT into the nucleus ambiguous, another area thought to be partially responsible for heart rate, caused an increase in activity in the vagal motor neurons, which, in turn, caused bradycardia (Jordan et al., 1988). In sum, it seems likely that $5-\mathrm{HT}_{1 \mathrm{~A}}$ receptors on the vagal motor neurons influence cardiac activity, and their activation by 5 -HT can reduce heart rate.

Though the relationship and mechanism(s) between heart rate and 5-HT is not completely understood, there is evidence supporting the idea that 5-HT, antidepressants and 5-HT $1 \mathrm{~A}$ agonists can affect cardiac function and heart rate, most likely by way of 5- $\mathrm{HT}_{1 \mathrm{~A}}$ receptor activation.

\section{Respiration Rate}

Much like with heart function, brainstem 5-HT neurons are also important for respiratory activity. The rostral ventrolateral medulla, or RVL, (an important area controlling respiration) receives 5-HT afferents from the dorsal raphe nuclei (Bianchi et al., 1995). However, there is conflicting evidence regarding the connection between respiratory rate and 5-HT.

Researchers have found that 5-HT application to the RVL causes respiration rate to increase, and then decrease. When the 5- $\mathrm{HT}_{2 \mathrm{~A}}$ antagonist ketanserin was administered, the decreasing effect of 5-HT was blocked. This suggests that 5- $\mathrm{HT}_{2 \mathrm{~A}}$ receptor activation influences respiratory rate. When researchers administered the 5- $\mathrm{HT}_{2}$ agonist, DOI, it caused increases in 
respiration rate (Onimaru et al., 1998). Additionally, the 5- $\mathrm{HT}_{2 \mathrm{C}}$ receptor agonist $\mathrm{m}-\mathrm{CPP}$ (Edwards et al., 1990), the 5-HT 1 в agonist CP-94253, and the relatively non-selective 5-HT agonist TFMPP (Heidenreich and Napier, 2000) all produce decreases in respiration rate.

Bo et al., (1987) found respiratory rate to decrease after the administration of citalopram to awake rabbits. Morrison and Heidenreich (2010) found that a majority of rats tested with citalopram showed a decrease in respiration rate, followed by a slight increase. Researchers suggest that a possible reason for this slight increase after high doses is that small increases in 5HT will decrease respiratory rate, while greater increases in 5-HT has to ability to reverse the effect.

It has been suggested that the 5- $\mathrm{HT}_{1 \mathrm{~A}}$ receptor plays a role in altering respiratory rate. Onimaru et al. (1998) found that with the administration of a low-concentration dose of 8-OHDPAT into the RVL, respiration rate equally increased and decreased. However, at high concentrations of 8-OH-DPAT, the respiration rate responses were mostly decreased from baseline. However, other researchers have actually found the opposite effect. Heidenreich and Kempel (2005) administered 8-OH-DPAT i.v. to anesthetized rats and found that respiration rate increased. Finally, King and Holtman (1990) found that respiratory rate was not changed at all after 8-OH-DPAT was applied to the ventral medulla.

It is clear that though the literature is conflicting, there is, indeed, evidence supporting the idea that 5-HT, 5-HT receptor ligands, and antidepressants, can alter respiration rate. 


\section{CHAPTER II: CURRENT STUDY}

For the current study, we aimed to investigate the effects of vortioxetine on neuronal activity in the VP, heart rate and respiration rate of urethane-anesthetized rats through electrophysiological techniques.

We hypothesized that:

H1: Vortioxetine would increase the frequency of action potentials in the majority of neurons in the ventral pallidum.

$\mathrm{H} 2$ : Vortioxetine would decrease the heart rate in the majority of rats tested.

H3: Vortioxetine would decrease the respiration rate in the majority of rats tested.

\section{Method}

\section{Subjects}

The current study used 6 male Sprague-Dawley rats obtained from Envigo (Indianapolis, IN). The rats weighed 275 grams to 450 grams and were housed in plastic tubs and allowed free access to food and water for the duration of the study. All animals were cared for in accordance with The Guide for the Care and Use of Laboratory Animals ( $8^{\text {th }}$ edition) of the National Institutes of Health. This research, including the protocols and methods, was approved by the Institutional Animal Care and Use Committee (IACUC).

\section{Materials and Procedure}

First, single barrel glass electrodes were pulled to the proper size, the tips broken so the diameter of the opening was $1-3 \mu \mathrm{m}$, and were filled with $1 \%$ pontamine sky blue dye in a $2 \mathrm{M}$ sodium chloride solution.

Rats were anesthetized with urethane (1.5 g per kg i.p.). Tests, such as a toe pinch, were conducted to ensure that the animal showed no pain reflexes during the procedure. Rats were 
then placed in a stereotaxic instrument equipped with a micromanipulator and secured with ear bars. A catheter was placed in the femoral vein for drug solution administration, as well as the maintenance of anesthesia. A metal clip was applied to the rat's chest for the electrophysiological recording of heart rate.

An incision was made in the scalp of the rat, exposing the skull. A hole was then drilled in the skull over the ventral pallidum region, $0.5 \mathrm{~mm}$ posterior and $2.2 \mathrm{~mm}$ lateral to bregma, determined by Paxinos and Watson's (1986) rat brain atlas. Next, an electrode was lowered into the brain of the rat until the tip was in place to record extracellular activity from a ventral pallidal neuron, at an approximate depth of 6.8 to $8.0 \mathrm{~mm}$. Activity throughout the duration of the experiment was monitored using an amplifier and filter with a window discriminator and was displayed with a digital storage oscilloscope. Action potentials would have been counted using Spike2 software on a PC computer equipped with a Micro 1401 interface. Baseline heart rate activity was recorded continuously for at least 5 minutes using Spike2 while respiration rate was counted manually during 30 second intervals.

After baseline recordings, rats were injected i.v. with increasing doses of vortioxetine (starting at $0.25 \mathrm{mg} / \mathrm{kg}$ ) in either a $0.9 \%$ sodium chloride or a $10 \%$ cyclodextrin solution every 2 minutes. Heart rate and respirations per 30 second intervals were recorded after each dose, using Spike2 software to analyze vortioxetine-induced effects. Changes in VP firing rate would have been considered significant if firing rate changed by $20 \%$ or more from baseline levels, and respiration and heart rate were considered significant if they changed by $3 \%$ or more from baseline levels after 2 successive injections, the same criteria that Morrison and Heidenreich (2010) used. 
After data collection, pontamine sky blue dye was ejected into the recording site. The rats were given an approximately $0.3 \mathrm{ml}$ dose of urethane and were transcardially perfused with $0.9 \%$ sodium chloride and $4 \%$ paraformaldehyde in $0.1 \mathrm{M}$ phosphate buffer. The brains were removed and stored in a paraformaldehyde solution for 24 hours, and then a $20 \%$ sucrose solution until the sectioning of the brain.

After 72 hours in sucrose, the brains were sectioned with a cryostat microtome at $40 \mu \mathrm{m}$ thick beginning at the anterior region of the VP. Brain sections were mounted onto slides and dried. The sections were rehydrated, stained with neutral red, defatted with ethanol and xylene, and then coverslipped. Microscopy allowed for confirmation of the proper location of recording (in the VP). Data would have only been used if recordings were taken from VP neurons.

The cubic regression method (Pitts et al., 1990) was used to determine Emax and ED50 values, as in previous work (Heidenreich and Napier, 2000). Emax is the maximal response that occurred for each rat. Its corresponding dose is simply the amount of the drug that is required to cause Emax. E1/2max is $50 \%$ of Emax, and ED50 is the amount of drug required to cause $\mathrm{E}^{1 / 2 \mathrm{max}}$. The cubic regression method is better in determining a best-fit function, as well as a better method for defining Emax and ED50 values, than linear regression. Pearson correlation coefficients and linear regression were used to examine the relationship between basal heart and respiration rates and the ED50s of vortioxetine. 


\section{CHAPTER III: RESULTS}

We hypothesized that vortioxetine would increase activity in the majority of VP neurons tested but were unable to collect data to test this hypothesis. We hypothesized vortioxetine would decrease heart rate in the majority of rats tested. Data from this experiment support this hypothesis. We hypothesized that vortioxetine would decrease respiration rate in the majority of rats examined. Data from this experiment do not support this hypothesis.

\section{Neural Activity}

We were unable to collect neuronal electrophysiological data that was of a high enough quality and for a sufficient duration to examine the effects of vortioxetine administration. Action potentials were observed at the presumed depth of the VP but often were not of a sufficient amplitude and signal-to-noise ratio to meet the standards for an acceptable recording. In some rats, action potentials that were acceptable were observed only for a period of time that was too short to perform data collection.

The difficulty in collecting neuronal recording data likely resulted from problems with our electrodes. We tried several ways to improve the quality of electrodes. The settings on the electrode puller were altered to determine if we could make better electrodes. This produced electrodes that were either too high or too low in impedance to be usable for recordings in the brain. It became necessary to use a different electrode puller. Unfortunately, the electrodes from this puller were unable to record action potentials as the electrode would increase in impedance shortly after entering the brain to the point that it was unusable. To combat this issue, we performed an experiment to see if we could determine a puller setting that created electrodes that did not increase in impedance in the brain. We soaked electrodes from different puller settings in $0.9 \%$ sodium chloride (to mimic the brain) for one hour and then measured their impedances. 
The setting of the electrodes that did not increase in impedance was noted and was used on all subsequent electrodes. However, when the electrodes were inserted into the brain, they still increased in impedance and were not usable. Finally, we changed the amplifier used with the electrodes to determine if that was the cause of the lack of acceptable activity. This had no effect. In sum, the experiment was performed without successful neuronal data collection. This experiment could be conducted again with technical issues resolved to allow for the recording of neural data.

\section{Heart Rate}

We recorded heart rate from 6 rats. Prior to the administration of vortioxetine, injections of the vehicle solutions for vortioxetine were given as controls. In animals 1 and 2, vortioxetine was dissolved in $0.9 \%$ sodium chloride. Because this solution was more of a suspension, a $10 \%$ solution of cyclodextrin in water was used as a vehicle to create a true solution of vortioxetine for animals 3 through 6 . Thus, animals 1 and 2 were injected with sodium chloride vehicle only, and animals 3 through 6 were injected with both the sodium chloride and cyclodextrin solutions. The sodium chloride control injection altered heart rate in the 6 rats by an average $1.0 \%$ from baseline, while the cyclodextrin injection increased heart rate by an average of $1.2 \%$ from baseline in the 4 rats tested. These responses are below our criteria for a significant change in heart rate, which must be met after at least two successive injections.

The responses in heart rate to vortioxetine are summarized in Table 1 . We observed that $67 \%(4 / 6)$ of rats showed heart rate responses that slightly increased from baseline and then decreased. In 1 of 6 rats (17\%), heart rate only decreased. One of 6 rats (17\%) showed no change in heart rate. 
Table 2 shows the mean, standard deviation, and standard error of the mean for the five heart rate responses that decreased, for each dose of vortioxetine, displayed cumulatively. There was a small average increase in heart rate after $0.25,0.5$, and $1 \mathrm{mg} / \mathrm{kg}$ cumulatively. Heart rate, on average, then returned to baseline, and then markedly decreased after 4,8 , and $16 \mathrm{mg} / \mathrm{kg}$ cumulatively. These results are displayed in Figure 1.

Table 3 displays the mean, standard deviation, and standard error of the mean of the average maximal response (Emax) value and its respective dose, as well as the $\mathrm{E}^{1 / 2} \mathrm{max}$ value and its respective dose (ED50), for the five heart rate responses that decreased. The Emax for heart rate was $84.2 \%$ of baseline, with a corresponding dose of $14.1 \mathrm{mg} / \mathrm{kg}$. The average $\mathrm{E}^{1} / 2 \mathrm{max}$ was $92.1 \%$ of baseline, with a corresponding ED50 of $7.8 \mathrm{mg} / \mathrm{kg}$. We also analyzed the correlation between baseline heart rate and the ED50 value for the five heart rate responses that decreased. There was no significant correlation $(\mathrm{r}=0.05)$, as shown in Figure 2.

\section{Respiration Rate}

We recorded respiration rate from the same 6 rats that were used to observe heart rate. As noted above, animals 1 and 2 were given control injections of sodium chloride only, and animals 3 through 6 were injected with both sodium chloride and cyclodextrin solutions prior to vortioxetine. In the 6 rats, the sodium chloride control injection altered respiration rate by an average $0.8 \%$ from baseline. The cyclodextrin injection changed respiration rate in 4 rats by an average of $0.6 \%$. These responses are below our criteria for a significant change in respiration rate, which must be met after at least two successive injections.

The responses in respiration rate to vortioxetine are summarized in Table 1. We observed that $50 \%(3 / 6)$ of rats had an increase in respiration rate after drug administration. In 1 of 6 rats 
(17\%), respiration decreased, while the remaining $33 \%(2 / 6)$ of rats did not show a change in respiration rate.

Table 2 shows the mean, standard deviation, and standard error of the mean for the 3 respiration rate responses that increased, for each dose of vortioxetine, displayed cumulatively. The first and second dose $(0.25$ and $0.5 \mathrm{mg} / \mathrm{kg}$ cumulatively) did not alter respiration rate. However, with the remaining doses, respiration rate increased. Two rats displayed a respiration rate that tapered off after the last two doses, and one rat's respiration rate plateaued during the last 3 doses. The dose-response curve for these results is displayed in Figure 3.

Table 3 displays the mean, standard deviation, and standard error of the mean of the Emax values and their respective dose, as well as the E1/2max value and ED50, for the three respiration rate responses that increased. For respiration, the Emax value was $125.4 \%$ of baseline, with a corresponding dose of $7.6 \mathrm{mg} / \mathrm{kg}$. The $\mathrm{E}^{1} / 2 \mathrm{max}$ value was $112.7 \%$ of baseline, with a corresponding ED50 of $1.4 \mathrm{mg} / \mathrm{kg}$.

We also analyzed the correlation between respiration rate and the ED50 value for the three respiration rate responses that increased. There was a negative correlation, $r=-0.93$; however, this value was not significant $(\mathrm{p}=0.25)$. These results are shown in Figure 4. 


\section{CHAPTER IV: DISCUSSION}

\section{General Discussion}

Our study showed that increasing doses of vortioxetine slightly increased, and then dramatically decreased heart rate in the majority of rats tested. This finding supports our hypothesis and is consistent with previous research. We also showed that increasing doses of vortioxetine most frequently increased respiration rate in the rats examined. Respiration rate increases did, however, show a trend of tapering off after the last two doses of vortioxetine. Despite that, our respiration rate results differ from what we hypothesized.

Vortioxetine's depressant effect on heart rate is consistent with its action as an SSRI and Morrison and Heidenreich's (2010) finding that the administration of the SSRI citalopram reduced cardiac activity in anesthetized rats. The exact neural mechanisms for the alteration of heart rate after antidepressant administration are unknown, but likely involve the activation of 5$\mathrm{HT}_{1 \mathrm{~A}}$ receptors. Since both vortioxetine and citalopram increase synaptic 5-HT in the brain where it is able to activate 5 -HT receptors, including the $5-\mathrm{HT}_{1 \mathrm{~A}}$ receptor, we suggest a link between the SSRI actions of vortioxetine and citalopram, the activation of 5-HT $\mathrm{H}_{1 \mathrm{~A}}$ receptors and regulation of heart rate.

This idea is supported by previous research linking 5-HT $\mathrm{HA}_{1 \mathrm{~A}}$ receptor activation and reductions in heart rate. Heidenreich and Kempel (2005) that found that the administration of the 5-HT $1 \mathrm{~A}$ agonist 8-OH-DPAT decreased heart rate in anesthetized rats. Vagal parasympathetic motor neurons in the DVM possess 5- $\mathrm{HT}_{1 \mathrm{~A}}$ receptors (Pazos \& Palacios, 1985) and application of 5-HT to the DVM results in bradycardia (Wang et al., 1995). Interestingly, vortioxetine's actions, not only as an SSRI but also as a direct 5-HT 1A $_{\text {A }}$ agonist, provides an additional mechanism for the reduction in heart rate observed in our study. 
In addition to its predominantly depressant effect on cardiac activity, vortioxetine produced slight but consistent increases in heart rate at the lowest doses tested. In this regard, vortioxetine differs from citalopram, which produced only progressive reductions in heart rate (Morrison and Heidenreich, 2010). As noted above, vortioxetine's additional action as a 5-HT $\mathrm{HT}_{1 \mathrm{~A}}$ agonist likely has a suppressant effect on cardiac activity. Thus, an increase in heart rate probably relates to vortioxetine's other properties as a $5-\mathrm{HT}_{1 \mathrm{~B}}$ receptor partial agonist or 5- $\mathrm{HT} 1 \mathrm{D}$, 5- $\mathrm{HT}_{3}$, and $5-\mathrm{HT}_{7}$ receptor antagonist. This experiment provides no evidence to distinguish between these possibilities.

In the present study, vortioxetine produced an increase in breathing rate in the majority of rats tested. This clearly represents a difference from the effects of citalopram, which consistently decreases respiration rate (Morrison and Heidenreich, 2010). While both drugs are SSRIs, citalopram is not a multimodal antidepressant and does not act on 5-HT receptors. In contrast, vortioxetine is, in fact, a multimodal antidepressant, with direct actions at multiple 5-HT receptor subtypes. We suggest that any of vortioxetine's other actions, including its $5-\mathrm{HT}_{1 \mathrm{~A}}$ agonism or 5$\mathrm{HT}_{1 \mathrm{D}}, 5-\mathrm{HT}_{3}$, and $5-\mathrm{HT}_{7}$ receptor antagonism, could have caused the increase in breathing rate observed with the current study.

One likely mechanism for vortioxetine's effect on respiration concerns its action as a 5$\mathrm{HT}_{1 \mathrm{~A}}$ receptor agonist and the role of these receptors on breathing. Application of 8-OH-DPAT into the RVL alters respiration rate (Onimaru, 1998). Furthermore, Heidenreich and Kempel (2005) observed increases in breathing rate after i.v administration of 8-OH-DPAT. It is a reasonable hypothesis that vortioxetine may have directly activated $5-\mathrm{HT}_{1 \mathrm{~A}}$ receptors, similar to 8-OH-DPAT, to increase breathing in the present study. In contrast, vortioxetine's action as a partial 5-HT 1 в agonist appears unlikely to explains our results. Heidenreich \& Napier (2000) 
found that i.v. injections of CP-94253, a 5-HT $1 \mathrm{~B}$ agonist, decreases respiration rate in anesthetized rats. Finally, it is possible that vortioxetine's action as a 5-HT $1 \mathrm{D}, 5-\mathrm{HT}_{3}$, and 5-HT receptor antagonist may have contributed to the increase in breathing rate we observed. I.v. administration of TFMPP, a non-selective 5-HT agonist, decreases respiration rate in anesthetized rats (Heidenreich \& Napier, 2000). If 5-HT $1 \mathrm{D}, 5-\mathrm{HT}_{3}$ or 5-HT $\mathrm{HT}_{7}$ receptors are tonically activated by endogenous 5-HT and function to reduce breathing rate, vortioxetine's actions as an antagonist could increase respiration.

In sum, it is a reasonable hypothesis that the additional receptor mechanisms of vortioxetine contributed to the increase in breathing rate that lessened at high doses. The idea that multiple effects of vortioxetine were involved seems likely. Two of our rats showed respiration rate results that "tapered off" for the final two doses of vortioxetine, and one showed a plateauing effect. The average dose for the mean Emax for respiration increases was less than half of the highest cumulative dose administered. Respiration rate after higher doses of the drug may reflect recruitment of additional actions, relative to that produced by the lower doses used.

In conclusion, the results of this experiment assist in determining if vortioxetine acts mostly as an SSRI, like citalopram, or if its multiple actions make it unique in its effects. For heart rate, vortioxetine produced responses similar to those expected of an SSRI. Regarding respiration, vortioxetine differs notably from citalopram in its effects, typically producing an increase (rather than a decrease) in breathing rate.

\section{Limitations}

The most significant limitation in our experiment was the inability to record electrophysiological data from neurons and test our first hypothesis. The procedures we used are generally considered standard techniques but are not without difficulty performing. Our belief is 
that the electrodes used in this experiment caused the majority of problems. While we tried a number of ways to improve the electrodes and their usability, we were not completely successful. However, this complication could be overcome in future work, and the first hypothesis in this research investigated.

The sample size for our analysis of the effect of vortioxetine on heart activity and breathing rate is small. While the results from the 6 rats examined seem unlikely to change dramatically, a larger sample would provide more definitive and conclusive values for some parameters. For example, there was a large $(r=-0.93)$ but non-significant correlation between basal respiration rate and the ED50 value of vortioxetine in the sample of 3 rats that increased breathing rate. A larger sample size likely would determine if this correlation is statistically significant and truly exists, or simply resulted from chance and limited observations.

Finally, future research on vortioxetine's effects may benefit from the use of specific 5HT receptor agonists and antagonists to shed additional light on the mechanisms involved. The ability of a receptor-selective drug to reverse the effect of vortioxetine may help determine the most important and relevant action(s) in influencing heart rate and respiration. 


\section{CHAPTER V: CONCLUSION}

This experiment aided in determining vortioxetine's effects on heart rate and respiration rate in the anesthetized rat. In summary, increasing doses of vortioxetine increased and then decreased heart rate, and increased respiration rate. It seems possible that the SSRI action of vortioxetine is responsible for the decreased heart rate, and the other multiple actions of the drug are responsible for the increased respiration rate. The results of the current research, as well as previous studies, indicate that $5-\mathrm{HT}_{1 \mathrm{~A}}$ receptor activation has a role in the regulation of heart rate and respiration rate. However, regardless of the mechanism, it is clear that vortioxetine has the ability to alter heart rate and respiration rate in rats.

The results of this study suggest possible mechanisms for alterations in heart rate and respiration rate observed after the administration of drugs affecting the 5-HT system. In the near future, this research may be important for developing other medications, especially antidepressants. The results of this experiment should be considered in future research involving further investigation of vortioxetine, as well as research involving 5-HT as it relates to heart rate and respiration rate. 


\section{REFERENCES}

Appel, N. M., Mitchell, W. M., Garlick, R. K., Glennon, R. A., Teitler, M., and De Souza, E. B. (1990). Autoradiographic characterization of

( \pm )-1-(2.5-dimethoxy-4-[1251]iodophenyl)-2-aminopropane ([1251]DOI) binding to

5-HT 2 and 5-HT $1 \mathrm{C}$ receptors in rat brain.J. Pharmacol. Exp. Ther., 255(2) 843-857.

Bengtson, C. P., Lee, D. J., \& Osborne, P. B. (2004). Opposing Electrophysiological Actions of 5-HT on Noncholinergic and Cholinergic Neurons in the Rat Ventral Pallidum In Vitro. Journal of Neurophysiology, 92(1), 433-443. doi:10.1152/jn.00543.2003

Bétry, C., Pehrson, A. L., Etiévant, A., Ebert, B., Sánchez, C., \& Haddjeri, N. (2013). The rapid recovery of 5-HT cell firing induced by the antidepressant vortioxetine involves $5-\mathrm{HT}_{3}$ receptor antagonism. The International Journal of Neuropsychopharmacology, 16(05), 1115-1127. doi:10.1017/s1461145712001058

Bianchi, A.L., Denavit-Saubie, M., \& Champagnat, J. (1995). Central control of breathing in mammals: Neuronal circuitry, membrane properties, and neurotransmitters. The American Physiological Society, 75, 1-45.

Blier, P., \& Bouchard, C. (1994). Modulation of 5-HT release in the guinea-pig brain following long-term administration of antidepressant drugs. British Journal of Pharmacology, 113(2), 485-495. doi:10.1111/j.1476-5381.1994.tb17015.x

Blier, P., \& Montigny, C. D. (1983). Electrophysiological investigations on the effect of repeated zimelidine administration on serotonergic neurotransmission in the rat. The Journal of Neuroscience, 3(6), 1270-1278. doi:10.1523/jneurosci.03-06-01270.1983 
Blier, P., \& Montigny, C. D. (1999). Serotonin and Drug-Induced Therapeutic Responses in Major Depression, Obsessive-Compulsive and Panic Disorders.

Neuropsychopharmacology, 21(2). doi:10.1016/s0893-133x(99)00036-6

Bo, P., Patrucco, M., Maurelli, M., Camana, C., \& Savoldi, F. (1987).

Neurophysiological changes induced by 5-HT reuptake inhibitors in rabbits. Il Farmaco: Edizione Scientifica, 42, 505-512.

Bockstaele, E. J., Chan, J., \& Pickel, V. M. (1996). Pre- and postsynaptic sites for serotonin modulation of GABA-containing neurons in the shell region of the rat nucleus accumbens. The Journal of Comparative Neurology, 371(1), 116-128. doi:10.1002/(sici)1096-9861(19960715)371:13.0.co;2-6

Campbell, A. D., \& Mcbride, W. J. (1995). Serotonin-3 receptor and ethanol-stimulated dopamine release in the nucleus accumbens. Pharmacology Biochemistry and Behavior, 51(4), 835-842. doi:10.1016/0091-3057(95)00050-7

Carlsen, J., Záborszky, L., \& Heimer, L. (1985). Cholinergic projections from the basal forebrain to the basolateral amygdaloid complex: A combined retrograde fluorescent and immunohistochemical study. Journal of Comparative Neurology, 234(2), 155-167. doi:10.1002/cne.902340203

Chaput, Y., Blier, P., \& Montigny, C. D. (1986). In vivo electrophysiological evidence for the regulatory role of autoreceptors on serotonergic terminals. The Journal of Neuroscience, 6(10), 2796-2801. doi:10.1523/jneurosci.06-10-02796.1986

Chaput, Y., Montigny, C. (1988). Effects of the 5-hydroxytryptamine1 receptor antagonist BMY 7378, on 5-hydroxytryptamine neurotransmission: Electrophysiological studies in the rat central nervous system. J. Pharmacol. Exp. Ther., 246(1), 359-370. 
Chrobak, J. J., \& Napier, T. C. (1993). Opioid and GABA modulation of accumbens-evoked ventral pallidal activity. Journal of Neural Transmission, 93(2), 123-143. doi:10.1007/bf01245342

Dale, E., Zhang, H., Leiser, S. C., Xiao, Y., Lu, D., Yang, C. R., Plath, N., Sanchez, C. (2014). Vortioxetine disinhibits pyramidal cell function and enhances synaptic plasticity in the rat hippocampus. Journal of Psychopharmacology, 28(10), 891-902. doi:10.1177/0269881114543719

Dale, E., Grunnet, M., Pehrson, A. L., Frederiksen, K., Larsen, P. H., Nielsen, J., Stensbøl T.B., Ebert, B., Yin, H., Lu, D., Liu, H., Jensen, T.N., Yang, C.R., Sanchez, C. (2018). The multimodal antidepressant vortioxetine may facilitate pyramidal cell firing by inhibition of 5- $\mathrm{HT}_{3}$ receptor expressing interneurons: An in vitro study in rat hippocampus slices. Brain Research, 1689, 1-11. doi:10.1016/j.brainres.2017.12.025

Davidson, C., \& Stamford, J. A. (1995). Evidence that 5-hydroxytryptamine release in rat dorsal raphé nucleus is controlled by $5-\mathrm{HT}_{1 \mathrm{~A}}, 5-\mathrm{HT}_{1 \mathrm{~B}}$ and $5-\mathrm{HT}_{1 \mathrm{D}}$ autoreceptors. British Journal of Pharmacology, 114(6), 1107-1109. doi:10.1111/j.1476-5381.1995.tb13321.x

Di Matteo, V., Blasi, A. D., Giulio, C. D., \& Esposito, E. (2001). Role of 5-HT2C receptors in the control of central dopamine function. Trends in Pharmacological Sciences, 22(5), 229-232. doi:10.1016/s0165-6147(00)01688-6

Edwards, E., Whitaker-Azmitia, P. M., \& Harkins, K. (1990). 5-HT ${ }_{1 \mathrm{~A}}$ and 5-HT $1 \mathrm{~B}$ agonists play a differential role on the respiratory frequency in rats. Neuropsychopharmacology, $30,1269-1277$. 
Engel, G., Gothert, M., Hoyer, D., Schlicker, E., \& Hillenbrand, K. (1986). Identity of inhibitory presynaptic 5-hydroxytryptamine (5-HT) autoreceptors in the rat brain cortex with 5-HT 1 в binding sites. Naunyn-Schmiedebergs Archives of Pharmacology, 332(1), 1-7. doi:10.1007/bf00633189

Eskelund, A., Li, Y., Budac, D. P., Müller, H. K., Gulinello, M., Sanchez, C., \& Wegener, G. (2017). Drugs with antidepressant properties affect tryptophan metabolites differently in rodent models with depression-like behavior. Journal of Neurochemistry, 142(1), 118-131. doi:10.1111/jnc.14043

Fort, P., Khateb, A., Serafin, M., Mühlethaler, M., \& Jones, B. E. (1998). Pharmacological characterization and differentiation of non-cholinergic nucleus basalis neurons in vitro. NeuroReport, 9(1), 61-65. doi:10.1097/00001756-199801050-00013

Gonda, X., Sharma, S. R., \& Tarazi, F. I. (2018). Vortioxetine: A novel antidepressant for the treatment of major depressive disorder. Expert Opinion on Drug Discovery, 14(1), 81-89. doi:10.1080/17460441.2019.1546691

Grove, E. A., Domesick, V. B., \& Nauta, W. J. (1986). Light microscopic evidence of striatal input to intrapallidal neurons of cholinergic cell group $\mathrm{Ch} 4$ in the rat: A study employing the anterograde tracer Phaseolus vulgaris leucoagglutinin (PHA-L). Brain Research, 367(1-2), 379-384. doi:10.1016/0006-8993(86)91623-9

Guillemin, G. J. (2012). Quinolinic acid, the inescapable neurotoxin. FEBS Journal, 279(8), 1356-1365. doi:10.1111/j.1742-4658.2012.08485.x 
Guilloux J.P., Mendez-David I., Pehrson A., Guiard B.P., Repérant C., Orvoën S., David, D.J. (2013). Antidepressant and anxiolytic potential of the multimodal antidepressant vortioxetine (Lu AA21004) assessed by behavioral and neurogenesis outcomes in mice. Neuropharmacology, 73, 147-159.

Haddjeri, N., Blier, P., \& Montigny, C. D. (1998). Long-Term Antidepressant Treatments Result in a Tonic Activation of Forebrain 5- $\mathrm{HT}_{1 \mathrm{~A}}$ Receptors. The Journal of Neuroscience, 18(23), 10150-10156. doi:10.1523/jneurosci.18-23-10150.1998

Heidenreich, B.A., Kempel, N.A. (2005). Program No.523.1. 2005 Neuroscience Meeting Planner. Washington, DC.

Heidenreich, B. A., \& Napier, T. C. (2000). Effects of serotonergic 5-HT 1 A and 5-HT 1 B ligands on ventral pallidal neuronal activity. NeuroReport, 1(13), 2849-2853. doi:10.1097/00001756-200009110-00005

Hopkins, D. A. (1987). The dorsal motor nucleus of the vagus nerve and the nucleus ambiguous: structure and connections. In R. Hainsworth, P.N. McWilliam, \& D.A.S.G. Mary (Eds.), Cardiogenic Reflexes (pp. 185-203). New York: Oxford University Press

Jones, B., \& Cuello, A. (1989). Afferents to the basal forebrain cholinergic cell area from pontomesencephalic — catecholamine, serotonin, and acetylcholine-neurons. Neuroscience, 31(1), 37-61. doi:10.1016/0306-4522(89)90029-8

Jordan, D., Izzo, P. N., \& Rampage, A. G. (1988). Evidence for the involvement of serotonin in central control of cardiac vagal motoneurons in the cat. Society for Neuroscience Abstracts, 14, 504. 
Khateb, A., Fort, P., Alonso, A., Jones, B. E., \& Mülethaler, M. (1993). Pharmacological and Immunohistochemical Evidence for Serotonergic Modulation of Cholinergic Nucleus Basalis Neurons. European Journal of Neuroscience, 5(5), 541-547. doi:10.1111/j.1460-9568.1993.tb00519.x

King, K. A. \& Holtman, J. R. (1990). Characterization of the effects of activation of ventral medullary serotonin receptor subtypes on cardiovascular activity and respiratory motor outflow to the diaphragm and larynx. The Journal of Pharmacology and Experimental Therapeutics, 252, 665-674.

Ladefoged, L. K., Munro, L., Pedersen, A. J., Lummis, S. C., Bang-Andersen, B., Balle, T., Schiøtt, B., Kristensen, A. S. (2018). Modeling and Mutational Analysis of the Binding Mode for the Multimodal Antidepressant Drug Vortioxetine to the Human 5- $\mathrm{HT}_{3 \mathrm{~A}}$ Receptor. Molecular Pharmacology, 94(6), 1421-1434. doi:10.1124/mol.118.113530

Leiser, S. C., Li, Y., Pehrson, A. L., Dale, E., Smagin, G., \& Sanchez, C. (2015). Serotonergic Regulation of Prefrontal Cortical Circuitries Involved in Cognitive Processing: A Review of Individual 5-HT Receptor Mechanisms and Concerted Effects of 5-HT Receptors Exemplified by the Multimodal Antidepressant Vortioxetine. ACS Chemical Neuroscience, 6(7), 970-986. doi:10.1021/cn500340j

Mansari, M. E., Lecours, M., \& Blier, P. (2015). Effects of acute and sustained administration of vortioxetine on the serotonin system in the hippocampus: Electrophysiological studies in the rat brain. Psychopharmacology, 232(13), 2343-2352. doi:10.1007/s00213-015-3870-9 Marcinkiewicz, M., Verge’, D., Gozlan, H., Pichat, L., \& Hamon, M. (1984). Autoradiographic evidence for the heterogeneity of 5-HT 1 sites in the rat brain. Brain Research, 291(1), 159-163. doi:10.1016/0006-8993(84)90664-4 
Marcus, M., Yasamy, M. T., Ommeren, M. V., Chisholm, D., \& Saxena, S. (2012). Depression: A Global Public Health Concern. PsycEXTRA Dataset. doi:10.1037/e517532013-004 McEwen, B. S., Angulo, J., Gould, E., Mendelson, S. (1993). Antidepressant modulation of isolation and restraint stress effects on brain chemistry and morphology. European Psychiatry, 8(2), 41-48.

Meredith, G. E., Pennartz, C. M., \& Groenewegen, H. J. (1993). The cellular framework for chemical signalling in the nucleus accumbens. Progress in Brain Research Chemical Signalling in the Basal Ganglia, 3-24. doi:10.1016/s0079-6123(08)61335-7

Meyer, J. H., Wilson, A. A., Sagrati, S., Hussey, D., Carella, A., Potter, W. Z., Ginovart, N., Spencer, E.P., Cheok, A., Houle, S. (2004). Serotonin Transporter Occupancy of Five Selective Serotonin Reuptake Inhibitors at Different Doses: A CDASB Positron Emission Tomography Study. American Journal of Psychiatry, 161(5), 826-835. doi:10.1176/appi.ajp.161.5.826

Morrison, T. R., \& Heidenreich, B. A. (2010). Effects of citalopram on ventral pallidal neuronal activity in vivo (Unpublished master's thesis). Illinois State University.

Nagaoka, I., Sasa, M., \& Yamawaki, S. (1998). 5-HT1A receptor-mediated inhibition of nucleus accumbens neurons activated by stimulation of parafascicular nucleus of thalamus. Psychopharmacology, 135(3), 230-235. doi:10.1007/s002130050504

Onimaru, H., Shamoto, A., \& Homma, I. (1998). Modulation of respiratory rhythm by 5-HT in the brainstem-spinal cord preparation from newborn rat. Pfugers Archive: European Journal of Physiology, 435, 485-494. 
Panagis, G., Spyraki, C., \& Miliaressis, E. (1995). Poststimulation excitability of ventral pallidum self-stimulation neurons. Behavioral Neuroscience, 109(4), 777-781. doi:10.1037/0735-7044.109.4.777

Parsons, L. H., \& Justice, J. B. (1993). Serotonin and Dopamine Sensitization in the Nucleus Accumbens, Ventral Tegmental Area, and Dorsal Raphe Nucleus Following Repeated Cocaine Administration. Journal of Neurochemistry, 61(5), 1611-1619. doi:10.1111/j.1471-4159.1993.tb09794.x

Paxinos, G., and Watson. 1986. The Rat Brain in Stereotaxic Coordinates, 2nd ed. Academic Press, New York.

Pazos, A., Cortés, R., \& Palacios, J. (1985). Quantitative autoradiographic mapping of serotonin receptors in the rat brain. I. Serotonin-1 receptors. Brain Research, 346, 205-230.

Pazos, A., Cortés, R., \& Palacios, J. (1985). Quantitative autoradiographic mapping of serotonin receptors in the rat brain. II. Serotonin-2 receptors. Brain Research, 346(2), 231-249. doi:10.1016/0006-8993(85)90857-1

Pehrson A.L., Cremers T., Betry C., van der Hart, M.G., Jørgensen, L., Madsen, M. Sanchez, C., (2013). Lu AA21004, a novel multimodal antidepressant, produces regionally selective increases of multiple neurotransmitters - a rat microdialysis and electrophysiological study. Eur Neuropsychpharmacology, 23, 133-145.

Pehrson, A., Nielsen, K. G., Jensen, J., \& Sanchez, C. (2012). The novel multimodal antidepressant Lu AA21004 improves memory performance in 5-HT depleted rats via 5- $\mathrm{HT}_{3}$ and 5- $\mathrm{HT}_{1 \mathrm{~A}}$ receptor mechanisms. European Neuropsychopharmacology, 22(2). doi:10.1016/s0924-977x(12)70405-4 
Pérez, P. D., Ma, Z., Hamilton, C., Sánchez, C., Mørk, A., Pehrson, A. L., . . Zhang, N. (2018). Acute effects of vortioxetine and duloxetine on resting-state functional connectivity in the awake rat. Neuropharmacology, 128, 379-387. doi:10.1016/j.neuropharm.2017.10.038

Pitts, D. K., Kelland, M. D., Shen, R. Y., Freeman, A. S., \& Chiodo, L. A. (1990). Statistical analysis of dose-response curves in extracellular electrophysiology studies of single neurons. Synapse, 5, 281-293.

Pollak-Dorocic, I., Fürth, D., Xuan, Y., Johansson, Y., Pozzi, L., Silberberg, G., Meletis, K. (2014). A Whole-Brain Atlas of Inputs to Serotonergic Neurons of the Dorsal and Median Raphe Nuclei. Neuron, 83(3), 663-678. doi:10.1016/j.neuron.2014.07.002

Pompeiano, M., Palacios, J., \& Mengod, G. (1992). Distribution and cellular localization of mRNA coding for 5- $\mathrm{HT}_{1 \mathrm{~A}}$ receptor in the rat brain: Correlation with receptor binding. The Journal of Neuroscience, 12(2), 440-453. doi:10.1523/jneurosci.12-02-00440.1992

Riad, M., Garcia, S., Watkins, K. C., Jodoin, N., Doucet, É, Langlois, X., el Mestikawy, S., Hamon, M., Descarries, L. (2000). Somatodendritic localization of 5-HT $1 \mathrm{~A}$ and preterminal axonal localization of $5-\mathrm{HT}_{1 \mathrm{~B}}$ serotonin receptors in adult rat brain. The Journal of Comparative Neurology, 417(2), 181-194. doi:10.1002/(sici)1096-9861(20000207)417:23.3.co;2-1

Roberts, C., Price, G. W., \& Jones, B. J. (1997). The role of 5-HT $1 \mathrm{~B} / 1 \mathrm{D}$ receptors in the modulation of 5-hydroxytryptamine levels in the frontal cortex of the conscious guinea pig. European Journal of Pharmacology, 326(1), 23-30. doi:10.1016/s0014-2999(97)00156-8 
Roberts, C., Thomas, D. R., Bate, S. T., \& Kew, J. N. (2004). GABAergic modulation of 5-HT 7 receptor-mediated effects on 5-HT efflux in the guinea-pig dorsal raphe nucleus. Neuropharmacology, 46(7), 935-941. doi:10.1016/j.neuropharm.2004.01.010

Root, D. H., Melendez, R. I., Zaborszky, L., \& Napier, T. C. (2015). The ventral pallidum: Subregion-specific functional anatomy and roles in motivated behaviors. Progress in Neurobiology, 130, 29-70. doi:10.1016/j.pneurobio.2015.03.005

Sanchez, C., Asin, K. E., \& Artigas, F. (2015). Vortioxetine, a novel antidepressant with multimodal activity: Review of preclinical and clinical data. Pharmacology \& Therapeutics, 145, 43-57. doi:10.1016/j.pharmthera.2014.07.001

Sari, Y. (2004). Serotonin receptors: From protein to physiological function and behavior. Neuroscience \& Biobehavioral Reviews, 28(6), 565-582. doi:10.1016/j.neubiorev.2004.08.008

Shirayama, Y., \& Chaki, S. (2006). Neurochemistry of the Nucleus Accumbens and its Relevance to Depression and Antidepressant Action in Rodents. Current Neuropharmacology, 4(4), 277-291. doi:10.2174/157015906778520773

Sizemore, G. M., Co, C., \& Smith, J. E. (2000). Ventral pallidal extracellular fluid levels of dopamine, serotonin, gamma amino butyric acid, and glutamate during cocaine self-administration in rats. Psychopharmacology, 150(4), 391-398. doi: $10.1007 / \mathrm{s} 002130000456$

Sprouse, J. S., \& Aghajanian, G. K. (1987). Electrophysiological responses of serotoninergic dorsal raphe neurons to 5-HT $1 \mathrm{~A}$ and 5-HT $1 \mathrm{~B}$ agonists. Synapse, 1(1), 3-9. doi:10.1002/syn.890010103 
Sprouse, J., \& Aghajanian, G. (1988). Responses of hippocampal pyramidal cells to putative serotonin 5- $\mathrm{HT}_{1 \mathrm{~A}}$ and 5- $\mathrm{HT}_{1 \mathrm{~B}}$ agonists: A comparative study with dorsal raphe neurons. Neuropharmacology, 27(7), 707-715. doi:10.1016/0028-3908(88)90079-2

Steinbusch, H. W. (1981). Distribution of serotonin-immunoreactivity in the central nervous system of the rat-cell bodies and terminals. Neuroscience, 6, 557-618.

Vysokanov, A., Flores-Hernandez, J., \& Surmeier, D. (1998). MRNAs for clozapine-sensitive receptors co-localize in rat prefrontal cortex neurons. Neuroscience Letters, 258(3), 179-182. doi:10.1016/s0304-3940(98)00882-9

Wang, Y., Jones, J. F., Ramage, A. G., \& Jordan, D. (1995). Effects of 5-HT and 5-HT 1 A receptor agonists and antagonists on dorsal vagal preganglionic neurones in anaesthetized rats: An ionophoretic study. British Journal of Pharmacology, 116(4), 2291-2297. doi:10.1111/j.1476-5381.1995.tb15067.x

Zahm, D., Zaborszky, L., Alones, V., \& Heimer, L. (1985). Evidence for the coexistence of glutamate decarboxylase and Met-enkephalin immunoreactivities in axon terminals of rat ventral pallidum. Brain Research, 325(1-2), 317-321. doi:10.1016/0006-8993(85)90331-2

Zangen, A., Nakash, R., Overstreet, D., \& Yadid, G. (2001). Association between depressive behavior and absence of serotonin-dopamine interaction in the nucleus accumbens. Psychopharmacology, 155(4), 434-439. doi:10.1007/s002130100746 


\section{APPENDIX A: TABLES}

Table 1. Overall responses for heart rate and respiration rate after increasing doses of vortioxetine. A criterion of 3\% or greater change from baseline for two successive injections was used to determine responses.

\begin{tabular}{lll}
\hline Animal \# & Heart Rate & Respiration Rate \\
\hline 1 & Decrease & Increase \\
2 & No change & No Change \\
3 & Increase/Decrease & Decrease \\
4 & Increase/Decrease & Increase \\
5 & Increase/Decrease & Increase \\
6 & Increase/Decrease & No Change \\
\hline
\end{tabular}


Table 2 .

Mean, standard deviation, and standard error of the mean for the five heart rate responses that decreased and the three respiration rate responses that increased after increasing doses of vortioxetine ranging from $.25-16 \mathrm{mg} / \mathrm{kg}$ cumulatively.

\begin{tabular}{|c|c|c|c|c|c|c|}
\hline \multirow{2}{*}{$\begin{array}{l}\text { Cumulative } \\
\text { Dose } \\
(\mathrm{mg} / \mathrm{kg})\end{array}$} & \multicolumn{3}{|c|}{ Heart Rate } & \multicolumn{3}{|c|}{ Respiration Rate } \\
\hline & Mean & $\begin{array}{l}\text { Standard } \\
\text { Deviation }\end{array}$ & $\begin{array}{l}\text { Standard } \\
\text { Error of } \\
\text { Mean }\end{array}$ & Mean & $\begin{array}{l}\text { Standard } \\
\text { Deviation }\end{array}$ & $\begin{array}{l}\text { Standard } \\
\text { Error of } \\
\text { Mean }\end{array}$ \\
\hline 0.25 & 103.5 & 6.4 & 2.9 & 100.5 & 5.2 & 3.0 \\
\hline 0.5 & 104.1 & 5.8 & 2.6 & 102.7 & 9.0 & 5.2 \\
\hline 1 & 103.1 & 7.4 & 3.3 & 111.5 & 13.2 & 7.6 \\
\hline 2 & 100.4 & 7.8 & 3.5 & 116.4 & 16.6 & 9.6 \\
\hline 4 & 96.2 & 11.5 & 5.1 & 126.3 & 9.2 & 5.3 \\
\hline 8 & 90.1 & 11.1 & 5.5 & 121.7 & 10.4 & 6.0 \\
\hline 16 & 84.4 & 8.6 & 3.8 & 116.4 & 10.2 & 5.9 \\
\hline
\end{tabular}




\section{Table 3.}

Mean, standard deviation, and standard error of the mean of Emax and E 1/2 max and their respective doses for the five heart rate responses that decreased and the three respiration rate responses that increased after increasing doses of vortioxetine ranging from $.25-16 \mathrm{mg} / \mathrm{kg}$ cumulatively.

\begin{tabular}{llll|lll}
\hline \multicolumn{3}{c}{ Heart Rate } & & \multicolumn{2}{l}{ Respiration Rate } \\
& Mean & $\begin{array}{l}\text { Standard } \\
\text { Deviation }\end{array}$ & $\begin{array}{l}\text { Standard } \\
\text { Error of } \\
\text { Mean }\end{array}$ & Mean & $\begin{array}{l}\text { Standard } \\
\text { Deviation }\end{array}$ & $\begin{array}{l}\text { Standard } \\
\text { Error of } \\
\text { Mean }\end{array}$ \\
\hline Emax & 84.2 & 8.9 & 4.0 & 125.4 & 10.1 & 5.8 \\
Emax dose & 14.1 & 2.7 & 1.2 & 7.6 & 4.5 & 2.6 \\
E 1/2max & 92.1 & 4.5 & 2.0 & 112.7 & 5.1 & 2.9 \\
ED50 & 7.8 & 4.2 & 1.9 & 1.4 & 0.7 & 0.4 \\
\hline
\end{tabular}




\section{APPENDIX B: FIGURES}

Figure 1. Dose-response curve for the five heart rate responses that decreased after administration of increasing doses of vortioxetine (filled circles). The Emax value and ED50 value are also displayed (open squares).

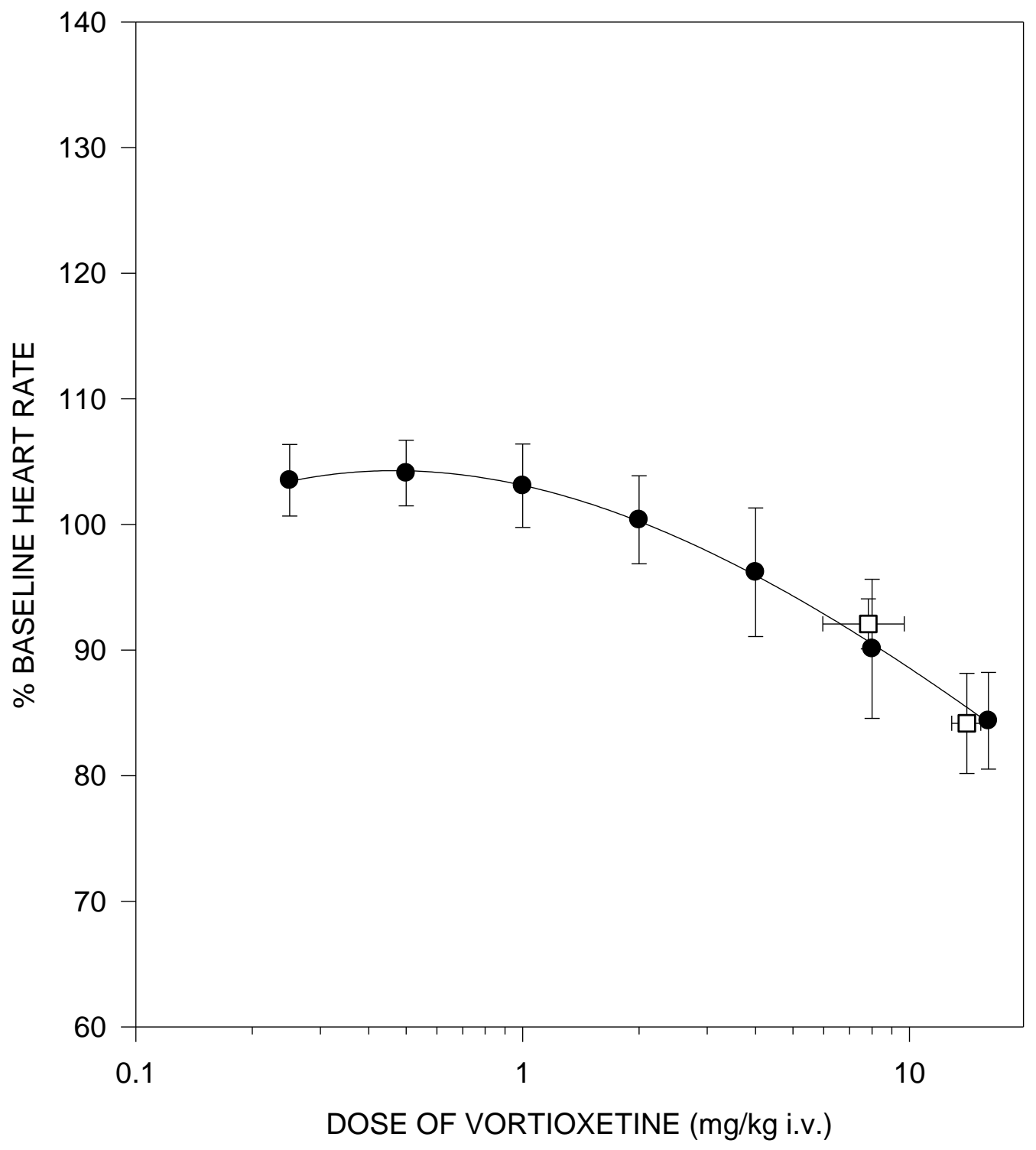


Figure 2. Correlation between baseline heart rate (beats/30 seconds) and ED50 for the five heart rate responses that decreased after the administration of increasing doses of vortioxetine. The correlation $(r=0.05)$ is not significant.

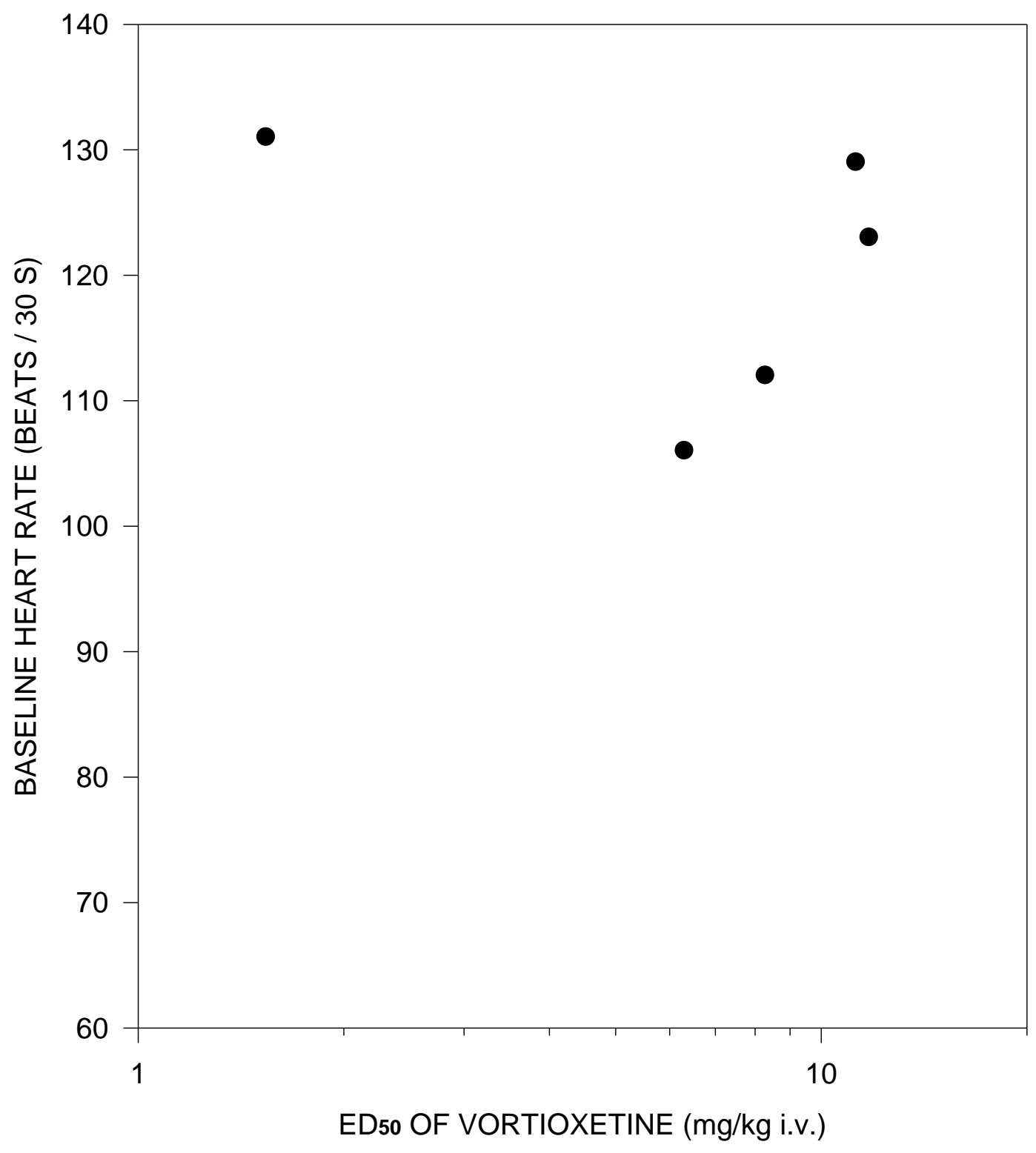


Figure 3. Dose-response curve for the three respiration rate responses that increased after administration of increasing doses of vortioxetine (filled circles). The Emax value and ED50 value are also displayed (open squares).

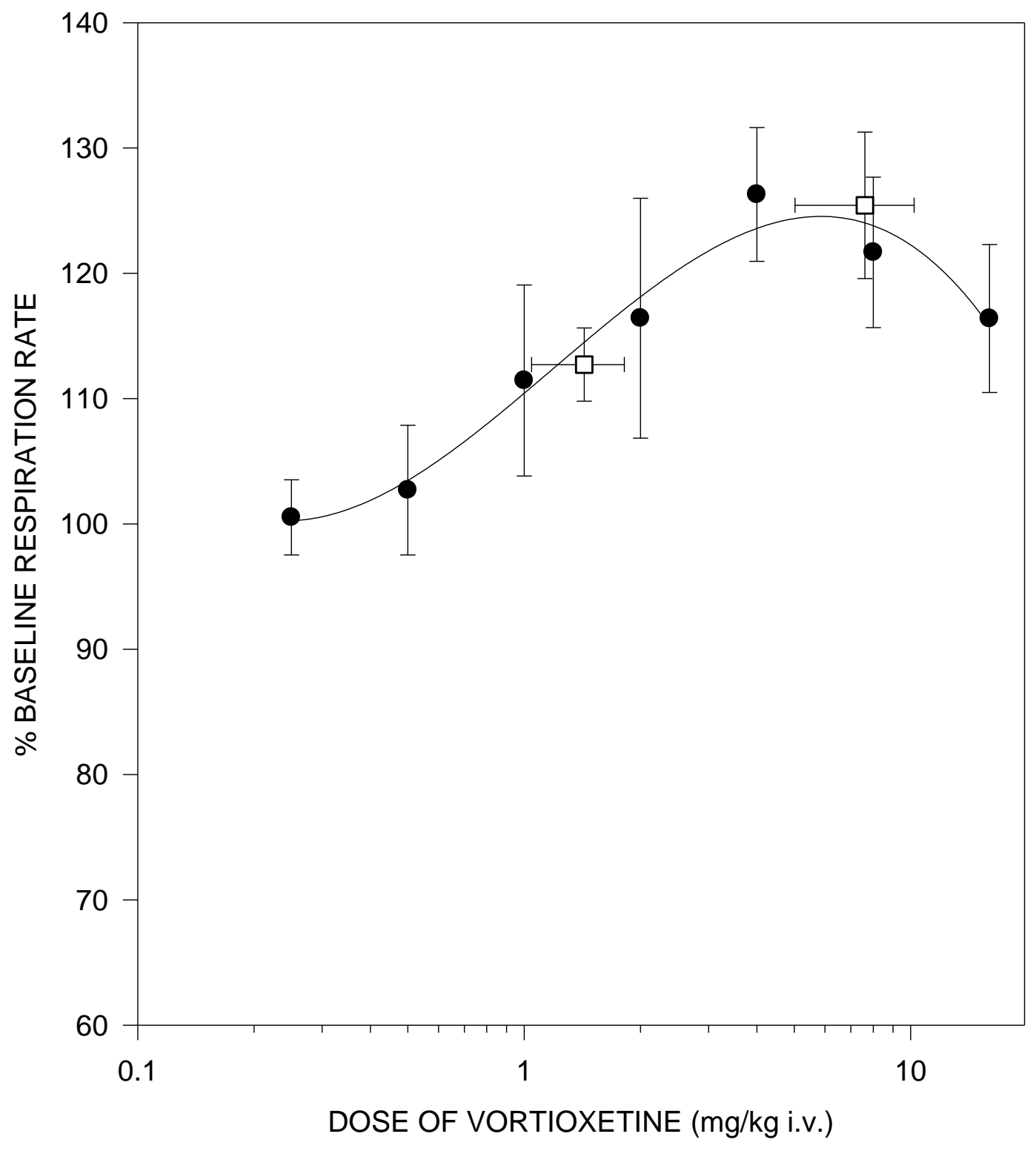


Figure 4. Correlation between baseline respiration (breaths/30 seconds) and ED50 for the three respiration rate responses that increased after the administration of increasing doses of vortioxetine. The correlation $(r=-0.93)$ is not significant $(p=0.25)$.

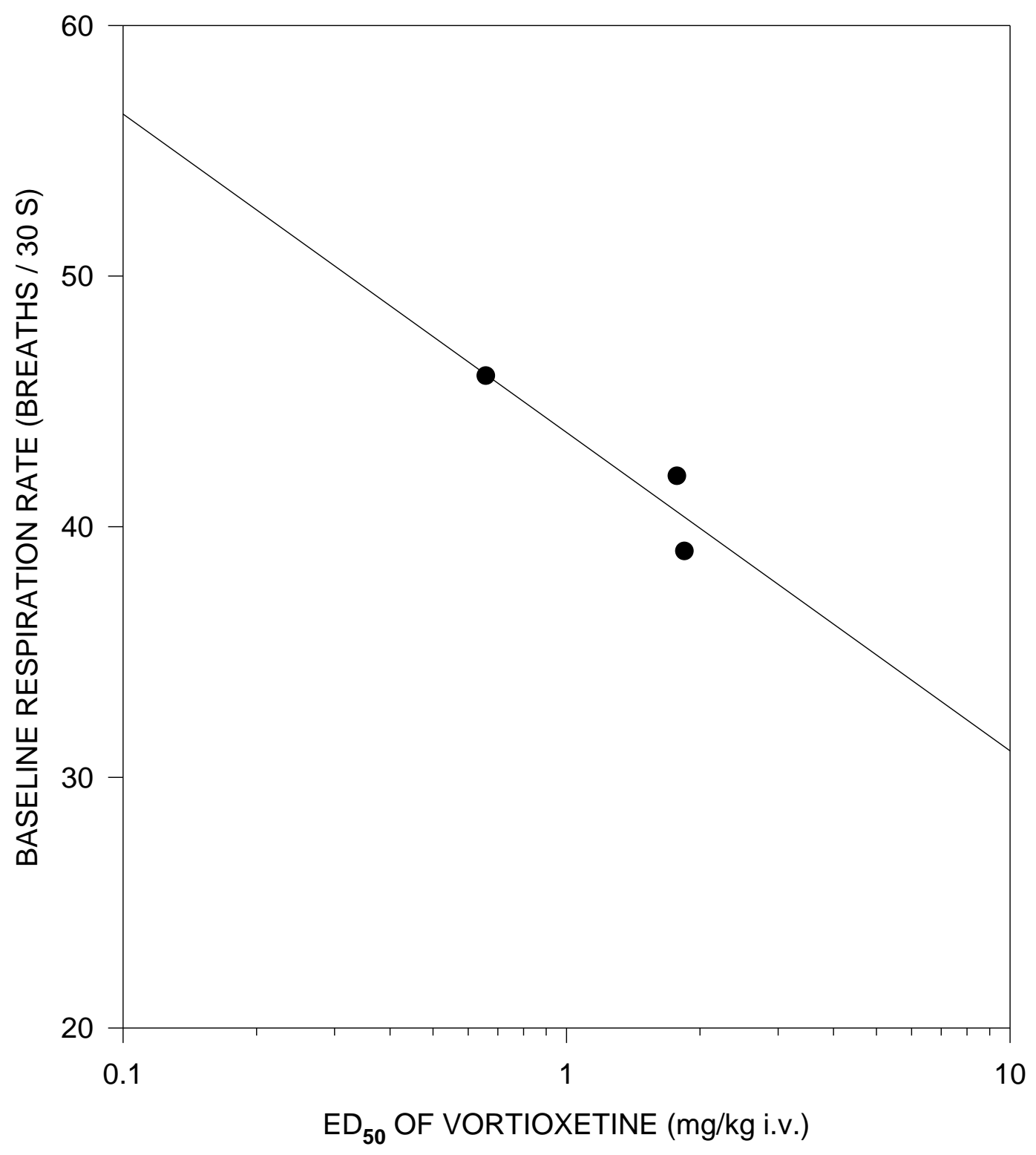

